Typical porcus is restricted by Rothschild \& Jordan to Cuba. The form continentalis differs, apart from variation in the genitalia, in the less prominent stigma of primaries, as well as the more pronounced discal dots; the olive green shading outside the cell is also reduced. Dr. Barnes has one specimen ex larv. from Florida.

(93) X. falco Walk.

Ariz.

Dr. Barnes has received three specimens of this species, bred by his collector in Arizona.

(94) X. tersa Linn.

Fla., Tex.

Genus Celerio Oken.

(95) C. gallii Rott.

(a) gallii intermedia Kirby. Me., Colo., Wyo., B. C., Alta. syn. chamcenerii Harr.

(96) C. lineata Fabr.

(a) lineata lineata. $\quad$ N. Y., Ill., Colo., Ariz., Fla.

\title{
NOTES ON THE SPECIES OF ANYTUS GRT.
}

By John B. Sмiтн, Sc. D.

Rutgers College, New Brunswick, N. J.

A recent re-arrangement of the genus made necessary by the accumulation of material has led to a somewhat closer study of the species, particularly with the view of fixing more accurately the standing of certain species. In Hampson's monograph $\mathrm{Ha}$ dena evelina French, is included under the generic term, in my opinion erroneously; altho I am probably no nearer right in placing it with Fishia. The other species recognized in the monograph are atristrigata Smith, privata Wlk., with monstrata Wlk., sculpta Grt., and plana Grt., as synonyms, profunda Sm., and obscura Sm. More recently I have described $A$. tenuilinea from a single example received from Stockton, Utah.

Anytus atristrigatus Smith, is from Texas and differs from all the other species by having a conspicuous and continuous black streak through the submedian interspace from base to the outer 
margin above the anal angle. The type of maculation is like that of privatus, but heavier, and the median lines are distinctly geminate. The types are both males.

Anytus privatus Wlk., better known as sculptus Grt., is of wide distribution throughout the eastern United States. While not one of the common species in most localities, it is by no means rare and flies in August and September. The squared, somewhat flattened thorax with its low divided creast recalls the Xyliniod genera and the type of maculation adds to this resemblance. But the wings are shorter and broader and the abdomen is not flattened. The colors are very light gray, resembling Acronycta so much that Walker described it once under the specific term monstrata, and the characteristic feature of the maculation is the indentation of the median lines in the sub-median interspace, supplemented by their connection through the black-edged and shaded claviform. The amount of black varies, so that there may be a very complete heavy bar dividing the median space, or there may be only a narrow line: the latter a somewhat rare form. There is little variation in other respects and the species once known is recognized with ease. The secondaries in the male are soiled white, outwardly powdery, with a blackish terminal line and some powdering on the veins. In the female the entire wing is a little smoky, an extra-median line is visible and usually also a discal spot.

The variety planus I have never seen. Mr. Grote describes it as having the median lines lost and the wing longitudinally shaded with whitish on median space, along internal margin, and diffusely beyond the reniform. None of the examples that I have seen even remotely approach this.

I have had under examination a series of 22 males and 25 females, most of them taken near Elizabeth, N. J., by Mr. Otto Buchholz, and they bring out nicely all variations that I have ever seen in the species.

Among my material, however, I picked out a series of five males and six females, that seemed different, and these I have named.

Anytus teltowa sp. nov.

Size and habitus of privatus, but darker throughout, the ground color of primaries being dark blue-gray instead of light ash-gray. In the male the secondaries 
are like those of female privatus, while in the female they are smoky throughout, darker outwardly, with the exterior line and discal spot obscured. The black markings of primaries are heavier and more diffuse throughout, and the $\mathrm{s}$. t. line is practically eliminated, the black shade which precedes the line in privatus continuing into and sometimes filling the terminal space.

Habitat: Hampton, N. H., IX, 20; Cohasset, Mass.; IX, 3; Elizabeth, N. J., IX, 2-20; Lakehurst, N. J., IX, 27; Vineland, N. J., VIII, 29.

The structure of the genitalia in this genus so far as I have studied them, gives little help in the separation of the species. The harpes are very strong, highly chitinized, somewhat twisted and asymmetrical. As a result no two mounts lie in exactly the same plane and no two figures are entirely alike. There is, however, a somewhat marked difference in the width of the harpes as between teltowa and privatus, and a difference in outline which is especially marked in the right harpe as seen in the picture. Several specimens of privatus were studied, but only one of teltowa, and the figure given of privatus is like all the specimens of that form examined. Atristrigatus was not studied for lack of sufficient material.

Anytus tenuilinea Smith, was described from a single female sent in by Mr. Spalding of Stockton, Utah, and derives its name from the slender transverse lines and other markings. Other differences exist and are pointed out in the original description; but the creamy gray base and very narrow maculation are sufficient for its ready recognition. The interesting point is that I find in the material received from Cohasset, Mass., through Mr. Bryant, an almost exact duplicate of the type, also a female, under date of September 6. There were a dozen examples, representing both teltowa and privatus, but only this one female stood out from all the rest as tenuilinea.

In 1900 I described, in the Canadian Entomologist XXXII, p. 218, Anytus obscurus from a single Calgary male sent in by $\mathrm{Mr}$. Dod, and Anytus profundus, from two Brandon, Man., males, sent in by Mr. Hanham. These species seemed to me distinct from the eastern privatus and from each other, though $\mathrm{I}$ realized that my material was scant. More material came in later, from the type and other localities, and I became distinctly doubtful of the validity of the separation. Sir George F. Hampson kept the 
species distinct in his monographic work; but Mr. Dod who has collected many examples, asserted that he had both forms represented in his captures and claimed that there was one species only.

A series of $28 \sigma^{7}$ and $23 \%$ from De Clair, Man., secured through Mr. H. H. Brehme, added to what I had from other sources, gave me a series of 65 examples of the two forms and, at first sight, separation seemed hopeless. More careful sifting, however, made matters easier, and I finally sorted out $50^{7}$ and 4 $\%$ as obscurus, all from Calgary, and the remainder, from Brandon, Cartwright, Miniota and De Clair, Manitoba, were all profundus. Obscurus is really well named and in the male differs obviously from profundus in a distinct brownish tinge, in the lack of contrasts, especially in the s. t. space, in the much more even, powdery suffusion over the whole wing, and in the lack of definition to the median lines.

Two males of obscurus and six of profundus were examined for genital structure and six figures, showing all noted variations, were made and are reproduced here for comparison. The harpes are asymmetrical and there is some little difference in each case; but the two obscurus stand out against the four profundus in the shorter, broader tip. The left harpe at tip shows in all profundus the little finger-like process at outer side below the level of tip which rises at once from the incision, while in obscurus the finger extends beyond the level of the border next adjoining. The differences are slight and perhaps not important; but for the present the superficial and other characters lead me to hold the two species as distinct.

\section{EXPLANATION OF PLATE 11.}

1. Anytus privatus: New York specimen.

2. Anytus teltowa: New Jersey specimen.

3. Anytus obscurus: Calgary specimen.

4. Anytus obscurus: Calgary specimen.

5. Anytus profundus: Brandon, Manitoba.

6. Anytus profundus: De Clair, Manitoba.

7. Anytus profundus: Meiniota, Manitoba.

8. Anytus profundus: Cartwright, Manitoba. 


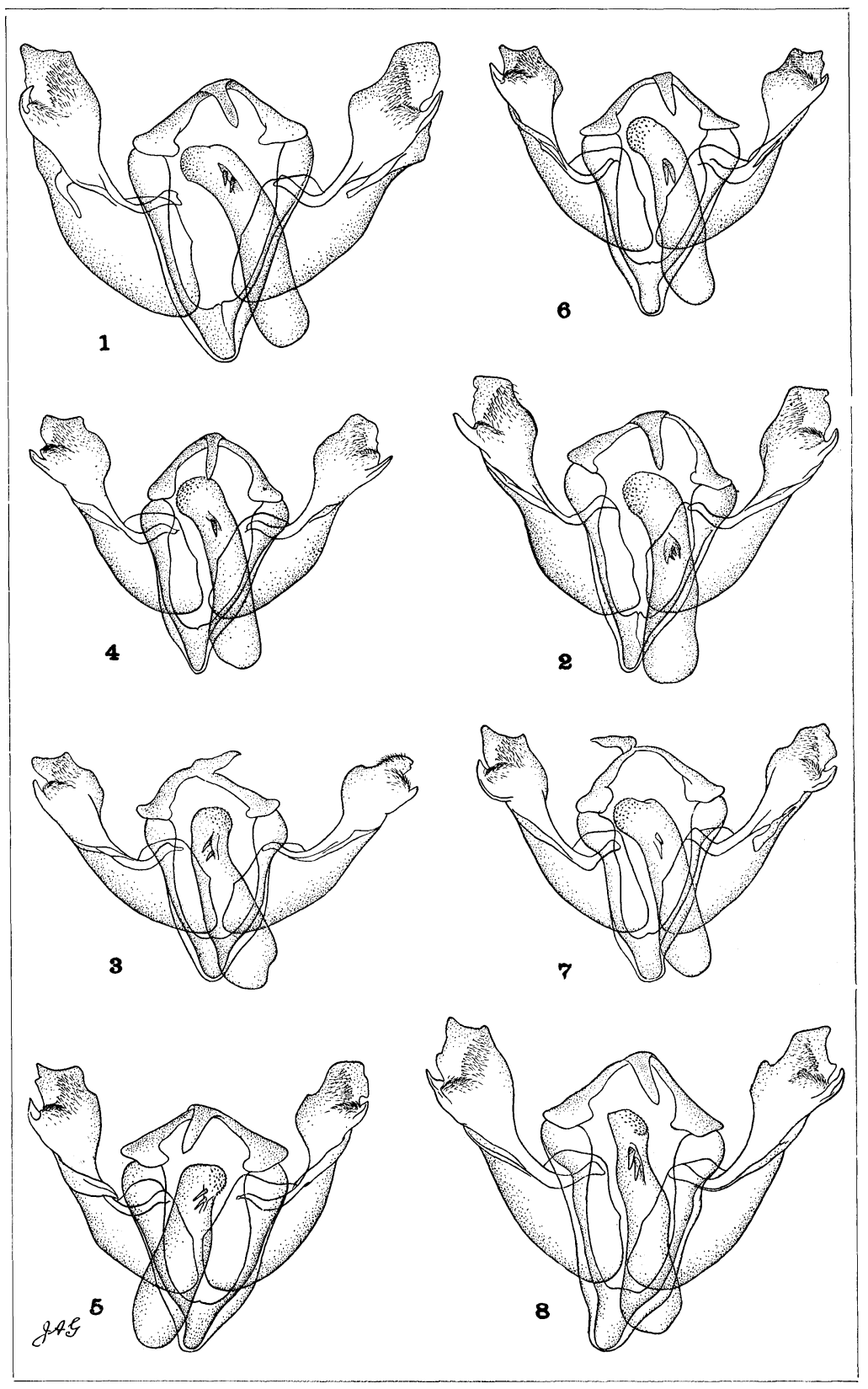

SMITH -. ANYTUS. 

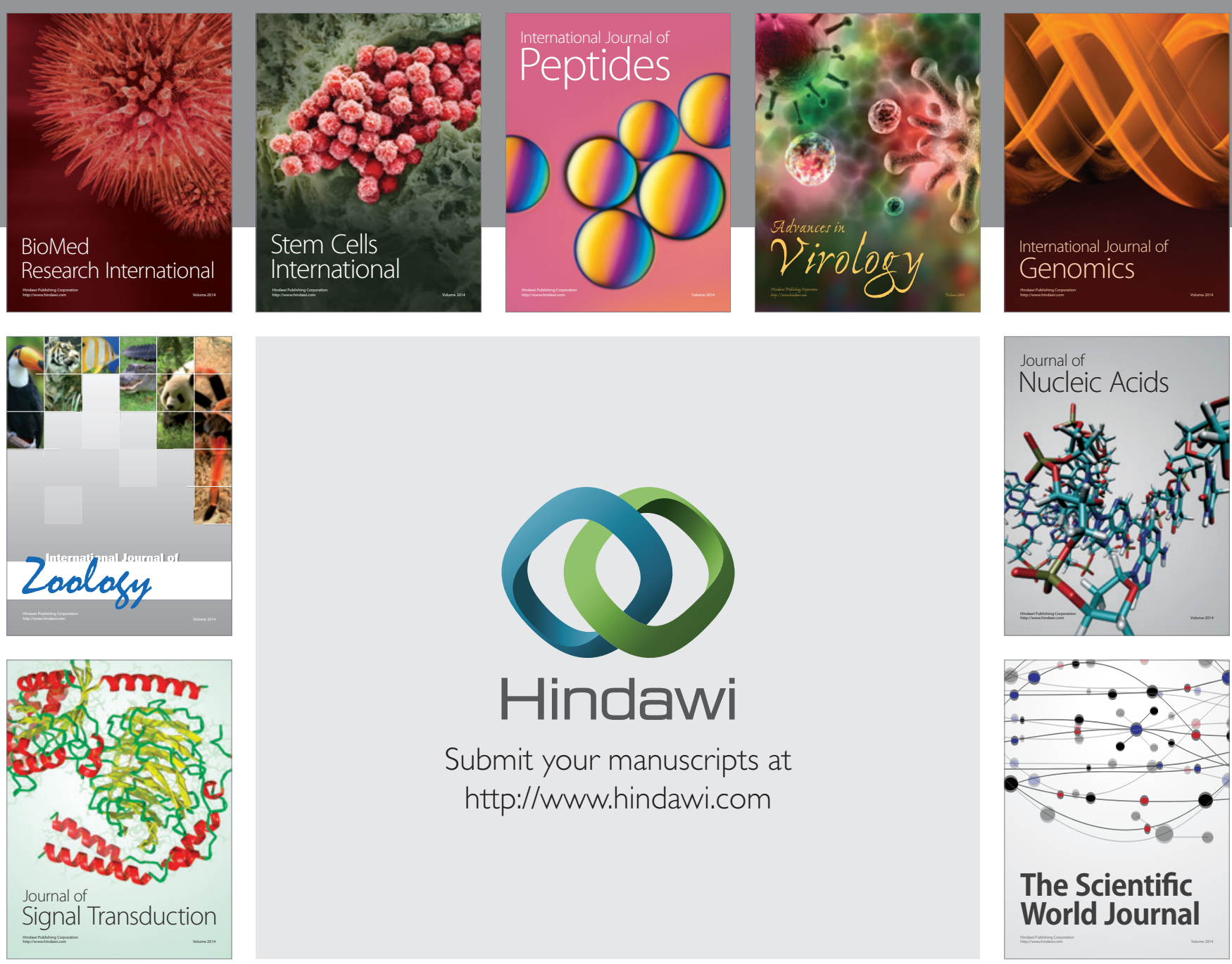

Submit your manuscripts at

http://www.hindawi.com
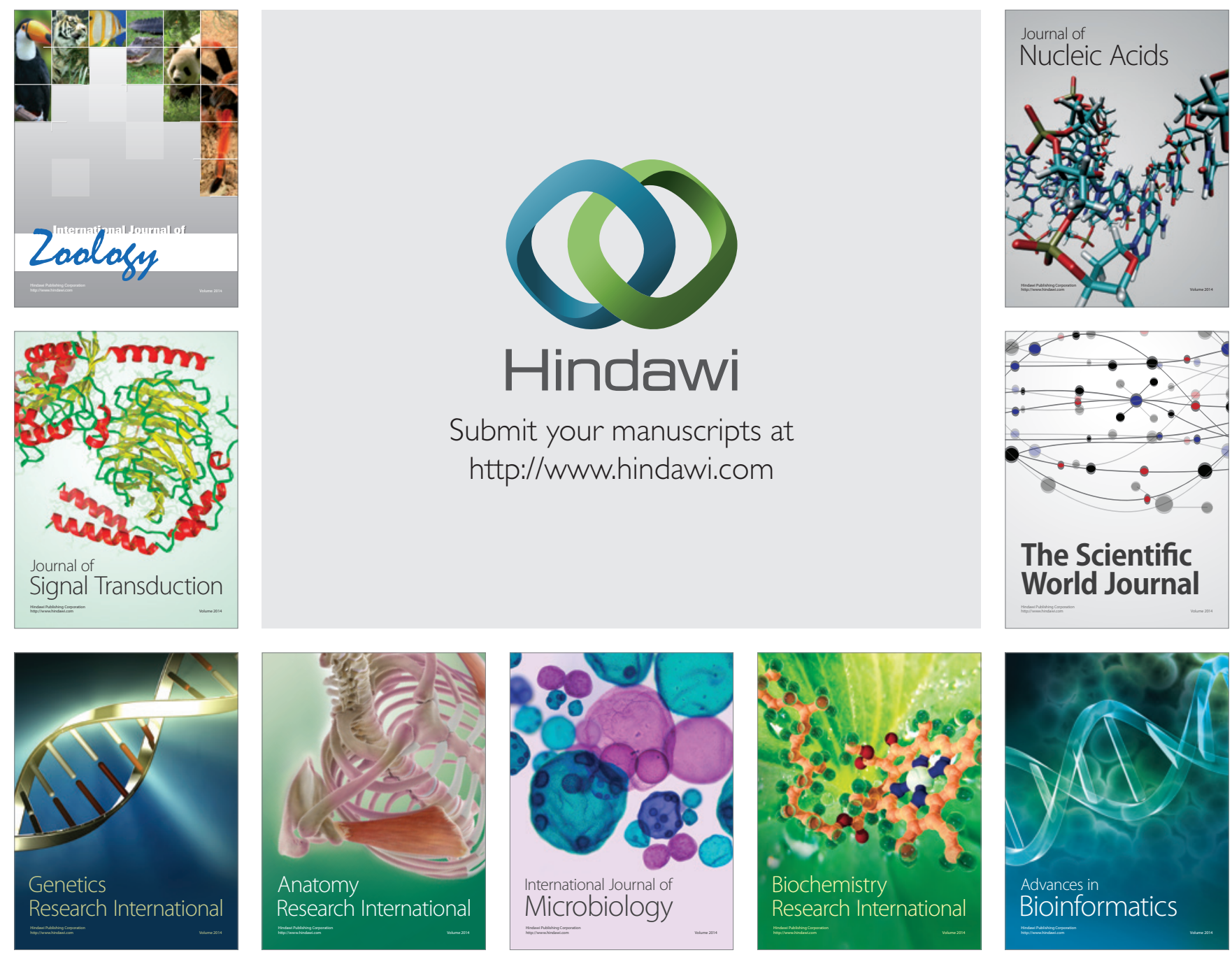

The Scientific World Journal
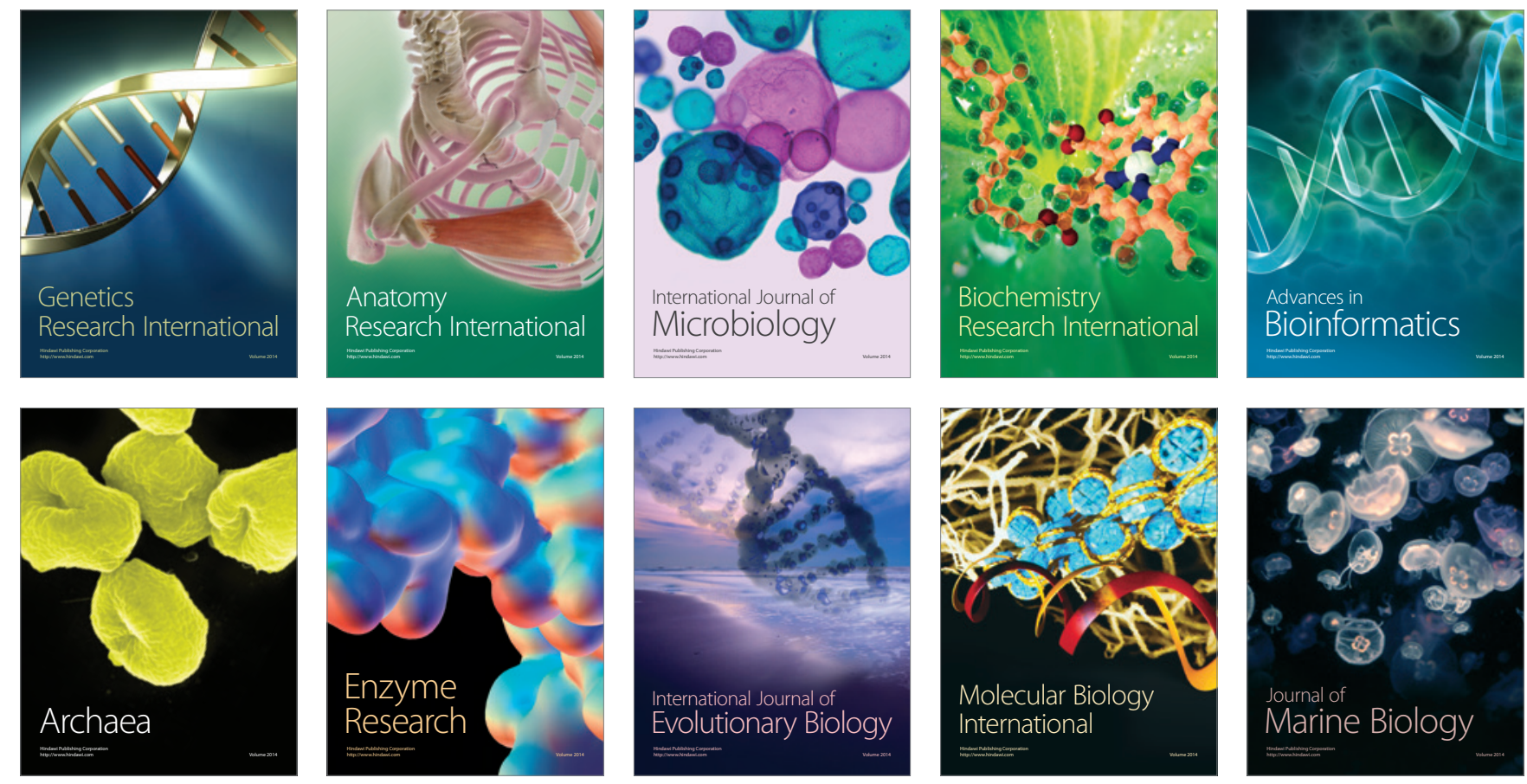